\title{
Clavarioid fungi and Gasteromycetes from Republic of São Tomé and Príncipe, West Africa
}

\author{
Desjardin $\mathrm{DE}^{1}$ and Perry $\mathrm{BA}^{2}$
}

\author{
${ }^{1}$ Department of Biology, San Francisco State University, 1600 Holloway Ave., San Francisco, California 94132, USA; \\ ded@sfsu.edu \\ ${ }^{2}$ Department of Biological Sciences, California State University East Bay, 25800 Carlos Bee Blvd., Hayward, \\ California 94542, USA; brian.perry@csueastbay.edu
}

Desjardin DE, Perry BA 2015 - Clavarioid fungi and Gasteromycetes from Republic of São Tomé and Príncipe, West Africa. Mycosphere 6(5), 515-531, Doi 10.5943/mycosphere/6/5/2

\begin{abstract}
Nine clavarioid-coralloid fungi and 14 gasteromycetes are reported from the islands of São Tomé and Príncipe. Of these 23 species, 14 are first reports for the Republic. Minimal descriptions, color photographs and comparisons with allied taxa are provided.
\end{abstract}

Key words - fungal diversity - mushrooms - Gulf of Guinea

\section{Introduction}

The earliest reports of fleshy macrofungi from São Tomé and Príncipe were those of Bresadola and Roumeguère (1890), who described collections made by Moller, Quintas and Newton in 1885. Although the majority of species they reported were polypores, a few agarics, clavarioid fungi, gasteromycetes, stereoid fungi, jelly fungi, ascomycetes and myxomycetes were included. Very limited fungal biodiversity research has since focused on the island nation. In April 2006 ( $2 \mathrm{wk}$ ) and April 2008 (3 wk), expeditions led by scientists from the California Academy of Sciences and joined by mycologists from San Francisco State University visited São Tomé and Príncipe to document the diversity of plants, amphibians, marine invertebrates and macrofungi. Initial accountings of the macrofungi collected during these expeditions were the publication of a new stinkhorn, Phallus drewesii Desjardin \& B.A. Perry, from São Tomé (Desjardin \& Perry 2009), and a new coral fungus, Scytinopogon havencampii Desjardin \& B.A. Perry, from Príncipe (Desjardin \& Perry 2015). We continue here with reports of additional clavarioid-coralloid fungi and gasteromycetes from the region.

\section{Materials \& Methods}

Specimens were dried on a Nesco food dehydrator, packed in airtight plastic bags and hand carried back to the US. Macromorphological data were derived from fresh specimens, whereas micromorphological data were derived from dried specimens rehydrated in ethanol followed by distilled water, $3 \% \mathrm{KOH}$ or Melzer's reagent. Color terms and notations are those of Kornerup and Wanscher (1978). All cited specimens are deposited in the H.D. Thiers Herbarium, Dept. of Biology, San Francisco State University (SFSU). 


\section{Taxonomy}

\section{Clavarioid Fungi}

Nine species of clavarioid-coralloid fungi are reported herein from the islands. Three of these were described originally from São Tomé island (Bresadola \& Roumeguère 1890), one from Príncipe island (Desjardin \& Perry 2015), and the remaining five species are first reports for the Republic.

Aphelaria subglobispora P. Roberts, Kew Bull. 54(3): 519. 1999.

Facesoffungi number: FoF 0106

Fig. 1, 5a

Basidiomes coralloid, 15-20 × 10-25 mm, erect, tough, pliant, coriaceous; branches polychotomous, flattened, arising from near the base; surface dull, smooth to rugulose; tips offwhite to buff, upper branches grayish orange (6B3), base of branches grayish brown (7D-E3), stipe off-white.

Basidiospores 5.0-5.7 $\times 4.5-5.2 \mu \mathrm{m}$, ovoid to subglobose, smooth, hyaline, with a distinct apiculus, eguttate. Basidia 33-40 × 5.7-6.7 $\mu \mathrm{m}$, subclavate, hyaline, 4-spored, clamped. Basidioles subcylindrical to subclavate. Cystidia absent. Dichophyses absent. Hymenium thickening. Hyphae 2-4 $\mu \mathrm{m}$ diam, cylindrical, smooth, hyaline, inamyloid, non-gelatinous, non-incrusted, thick-walled.

Habitat and known distribution - Solitary, in clumps in soil in secondary forest with coconut and rattan.

Material examined - Africa, Príncipe island, east side of island at the base of Dois Irmãos, N1³4.889', E7²5.548', 23 April 2008, coll. by D.E. Desjardin, DED8317 (SFSU).

Notes - Aphelaria subglobispora was described from Cameroon. Basidiomes are similar in shape and pigmentation to small forms of A. dendroides (Jungh.) Corner (1950), but the latter usually forms larger basidiomes (up to $70 \mathrm{~mm}$ tall) with larger basidiospores $7.5-9 \times 7-8 \mu \mathrm{m}$ and clampless hyphae. Aphelaria tuberosa (Grev.) Corner is also similar, but forms subfusoid basidiospores 14-20 × 5-7 $\mu \mathrm{m}$ on much larger basidia (Corner 1950). Aphelaria ceracea Corner differs in forming white basidiomes that develop on the bark of Quercus trees in Pakistan (Corner 1970).

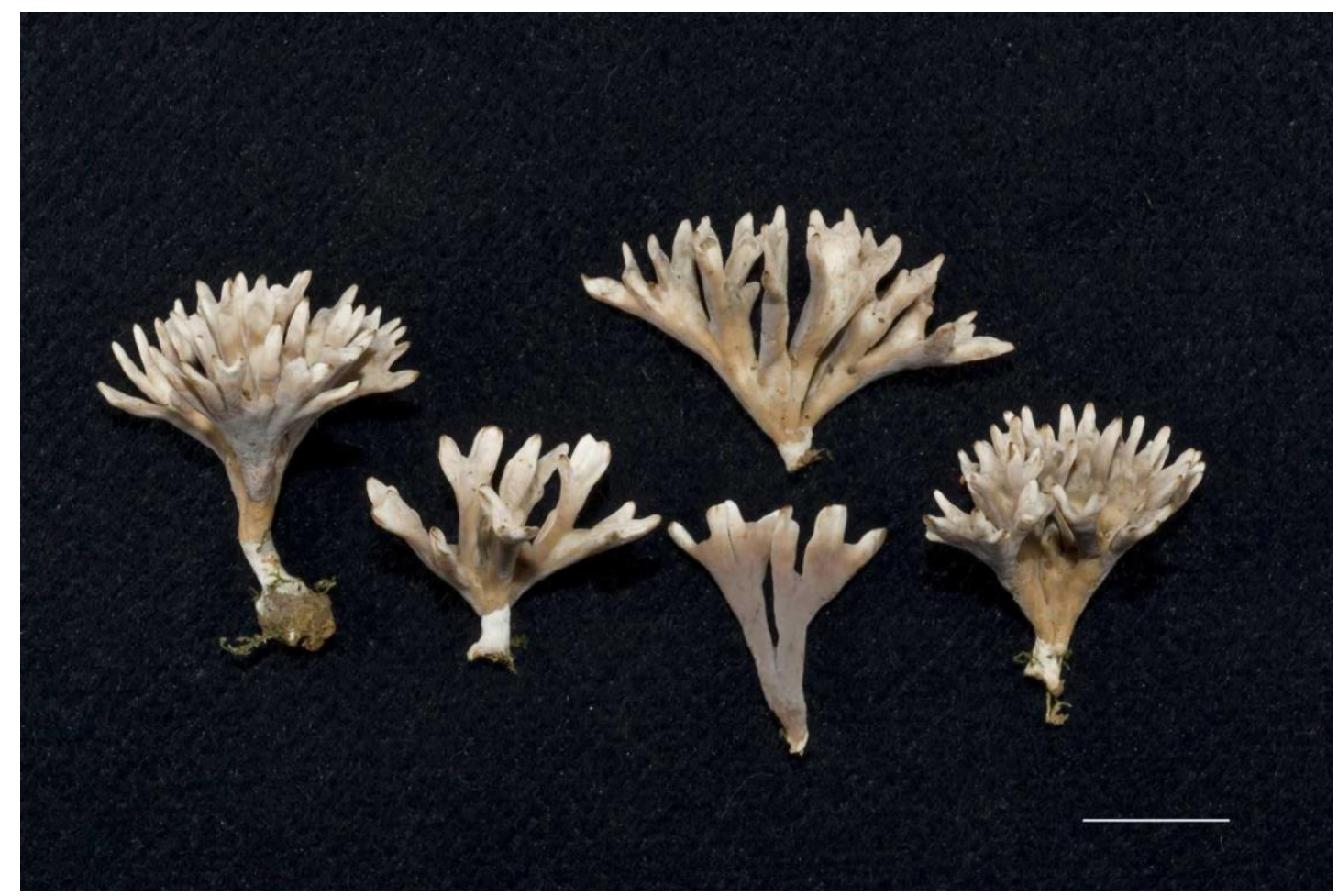

Fig. 1 - Basidiomes of Aphelaria subglobispora (DED8317). Scale bar $=10 \mathrm{~mm}$. 
Clavaria phoenicea Zoll. \& Moritzi, Natuur-Geneesk. Arch. Ned.-Indië 1: 380. 1844. Facesoffungi number: FoF 01062

= Clavulinopsis miniata var. ealaensis (Beeli) Corner, Bull. Jard. Bot. État Brux. 36(3): 258. 1966.

= Clavaria phoenicea var. ealaensis Beeli, Bull. Soc. R. Bot. Belg. 58: 209. 1926.

Basidiomes simple, club-shaped or with $2-4$ branches, $30-60 \mathrm{~mm}$ tall $\times 2-3 \mathrm{~mm}$ diam, compressed, tips acute; surface smooth to rugulose, glabrous, pale coral red (8-9A6), fading in age to pink. Odor indistinct.

Basidiospores 5.5-6 $\times 5.5-5.7 \mu \mathrm{m}$, globose to subglobose, smooth, hyaline, thin-walled. Basidia 4-spored, clamped. Hyphae hyaline, clamped.

Habitat and known distribution - Cespitose in soil in secondary upland forest. Africa (DR Congo, Príncipe), widespread in tropical Asia.

Material examined - Africa, Príncipe island, trail at Roca Pico Papagaio, N1 ${ }^{\circ} 37.182^{\prime}$, E7 $23.474 '$, elev. 250 m, 21 April 2008, coll. by B.A. Perry and D.E. Desjardin, BAP643 (SFSU).

Notes - Clavaria phoenicea was reported from Cameroon (Roberts 1999) with narrower basidiospores (4.5-5.5 $\mu \mathrm{m}$ diam), and from the DR Congo as Clavulinopsis miniata var. ealaensis based on coral pink basidiomes with slightly larger, more ellipsoid basidiospores 6.7-7.5 × 5.5-6.3 $\mu \mathrm{m}$ (Corner 1966).

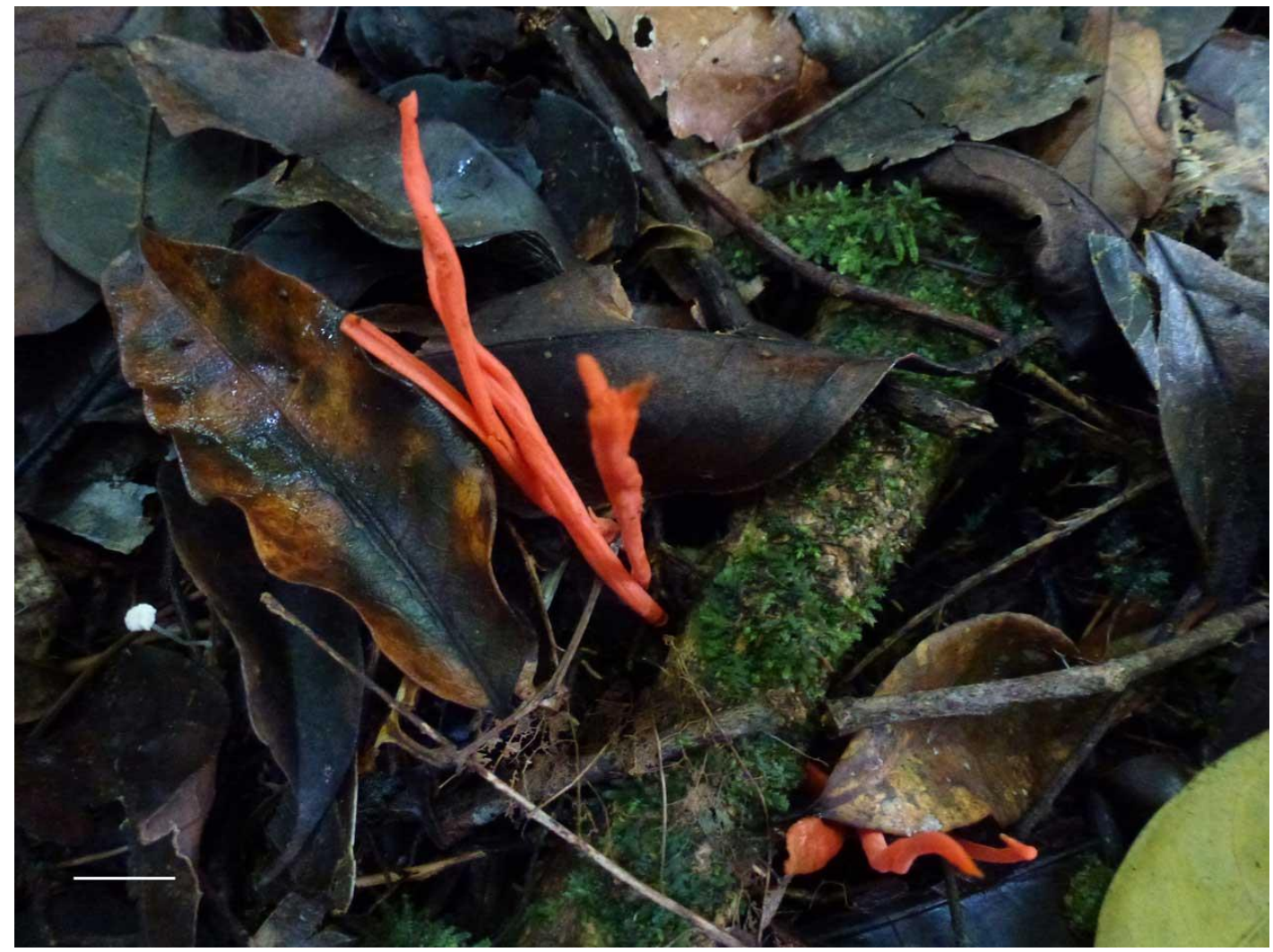

Fig. 2 - Basidiomes of Clavaria phoenicea. Scale bar $=10 \mathrm{~mm}$.

Clavulina vanderystii (Bres.) Corner, Ann. Bot. Mem. 1: 341. 1950.

Figs. 3, 5c

Facesoffungi number: FoF 01063

Basionym: Lachnocladium vanderystii Bres., Bull. Jard. Bot. État Brux. 4: 25. 1913.

Basidiomes coralloid, 50-70 × 40-50 mm. Stipe cespitose, connivent, 20-30 × 2.5-5 mm, polychotomously branched above, solid; surface white-pruinose over dark orangish brown $(5 \mathrm{C}-$ D5-6) ground color. Branches 1-2 mm diam, dichotomous to polychotomous, subcompressed, axils angular, acute; surface rugulose, glabrous to minutely pruinose, pale orangish white to grayish white; tips 2-4-fid, sharply pointed, white. Odor sweet, wax-like. 
Basidiospores 7-8.5 × 6.5-7.0 $\mu \mathrm{m}$, subglobose, smooth, hyaline, thin-walled. Basidia 2spored, clamped. Hyphae hyaline, clamped.

Habitat and known distribution - Scattered in rocky soil in primary coastal forest. Africa (DR Congo, Príncipe).

Material examined - Africa, Príncipe island, mouth of the Rio São Tomé, N1 $38^{\prime} 40.45^{\prime \prime}$, E7²1'15.5", elev. 30 m, 22 April 2008, coll. by B.A. Perry, BAP647 (SFSU).

Notes - Lachnocladium vanderystii was described from the DR Congo as forming "luride alutaceis" stems, and the material from Príncipe matches nicely. Corner (1950) made the transfer into Clavulina, but later (Corner 1966) accepted the taxon as a synonym of the apparently invalid epithet $C$. cristata var. nivea Bourd. \& Galz. The latter represents a European taxon with white to cream basidiomes with palmately divided branches and blunt to subulate tips, clearly distinct from the African species presented here. Clavulina coffeoflava P. Roberts, described from Cameroon, is similar but has pale yellow to café-au-lait branches and white to cream stipe, and ellipsoid basidiospores 7-8 × 5-6 $\mu \mathrm{m}$ (Roberts 1999).

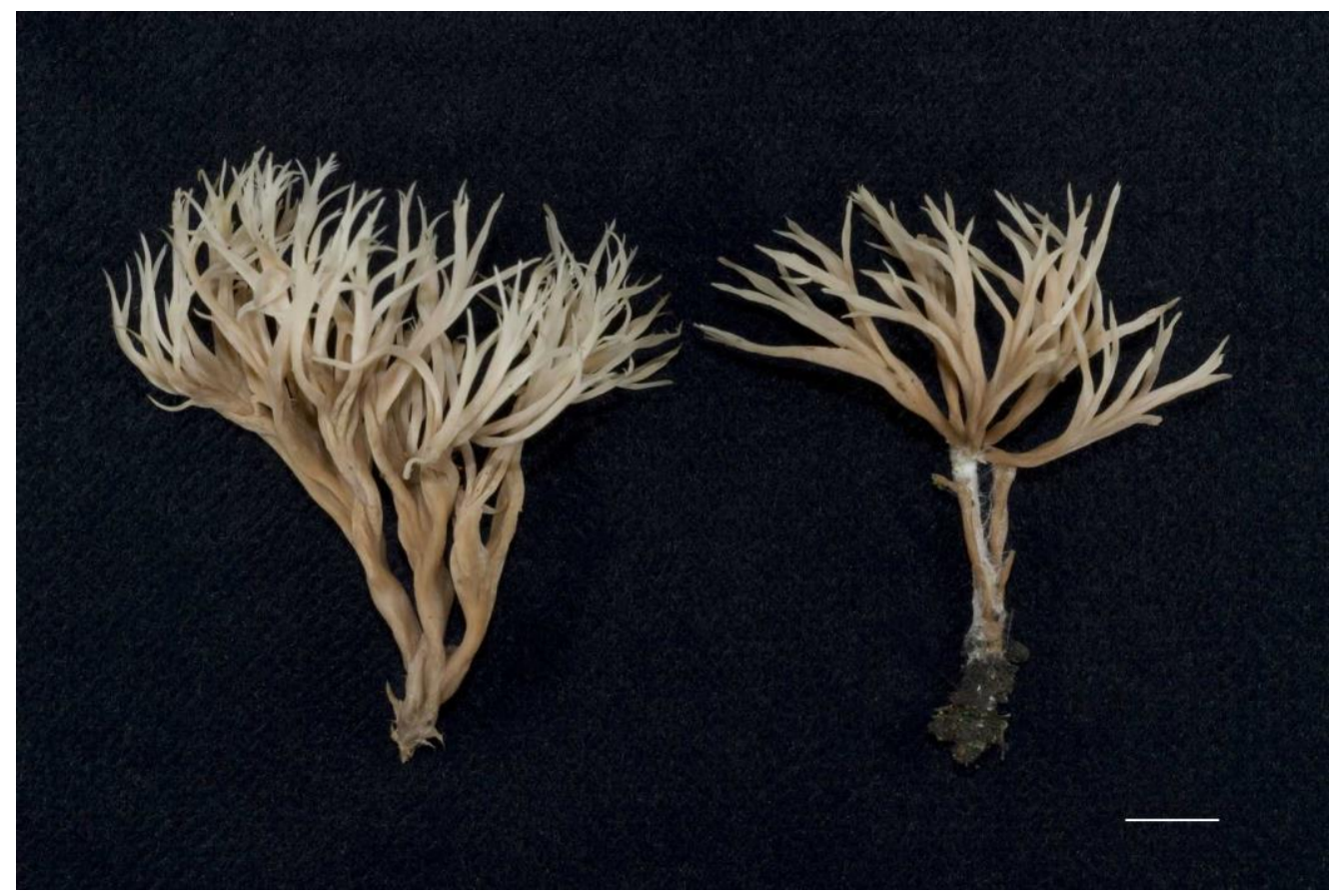

Fig. 3 - Basidiomes of Clavulina vanderystii (BAP647). Scale bar $=10 \mathrm{~mm}$.

Clavulinopsis amoena (Zoll. \& Moritzi) Corner, Ann. Bot. Mem. 1: 352.1950. Facesoffungi number: FoF 01064

Fig. $5 d$

Basionym: Clavaria amoena Zoll. \& Moritzi, Natuur-Geneesk. Arch. Ned.-Indië 1: 380. 1844.

Basidiomes simple, club-shaped, $12-45 \times 0.5-1.5 \mathrm{~mm}$, apex slightly broader, tapered downward, cespitose; surface glabrous, deep orange (4-5A7-8).

Basidiospores 5.5-6 $\times 4.3-5.0 \mu \mathrm{m}$, subglobose to slightly angular, smooth, with a large guttule, hyaline, thick-walled. Basidia 4-spored, clamped. Hyphae hyaline, clamped.

Habitat and known distribution - Cespitose in soil in secondary upland forest. Africa (DR Congo, Príncipe), widespread in tropical Asia.

Material examined - Africa, Príncipe island, trail at Roca Pico Papagaio, N1³7.182', E7²3.474', elev. 250 m, 21 April 2008, coll. by B.A. Perry and D.E. Desjardin, BAP642 (SFSU).

Notes - Clavulinopsis amoena was originally described from Java, and subsequently reported as rather widespread in tropical Asia (Sri Lanka, Malaysia, Indonesia, Bonin Islands) (Corner 1950). It was first reported from western Africa by Corner (1966), based on pale yellowishochre basidiomes collected by M. Goossens-Fontana in the DR Congo. The Príncipe specimen is 
more orange than yellow.

Pterulicium xylogenum (Berk. \& Broome) Corner, Ann. Bot. Mem. 1: 538. 1950. Facesoffungi number: FoF 01065

Basionym: Clavaria xylogena Berk. \& Broome, J. Linn. Soc., Bot. 14(74): 76. 1863 (1875).

Synonym: Pterula subaquatica Bres. \& Roum., Rev. Mycol., Toulouse 12(45): 36. 1890.

Notes - Bresadola and Roumeguere (1890) described Pterula subaquatica from material collected on dead aquatic plants on São Tomé. Corner (1950) accepted it as a synonym of Pterulicium xylogenum and noted that it grows on dead wood, dead bamboo culms, and dead leaf sheaths and trunks of palms throughout southeast Asia. No São Tomé material was examined for this study.

Ramaria henriquesii (Bres. \& Roum.) Corner, Ann. Bot. Mem. 1: 596. 1950. Facesoffungi number: FoF 01066

Basionym: Clavaria henriquesii Bres. \& Roum., Rev. Mycol., Toulouse 12(45): 36. 1890.

Notes - Clavaria henriquesii was described from São Tomé in 1890, based on a single specimen and the species has apparently not been encountered since. Corner (1950) transferred the species to Ramaria, although the rather large $(9-11 \times 9 \mu \mathrm{m})$, globose to ellipsoid, smooth basidiospores are unusual in that genus, and more characteristic of a Clavulina. No São Tomé material was examined for this study.

Ramaria molleriana (Bres. \& Roum.) Corner, Ann. Bot. Mem. 1: 606. 1950. Facesoffungi number: FoF 01067

Basionym: Lachnocladium mollerianum Bres. \& Roum., Rev. Mycol., Toulouse 12(45): 36. 1890.

Notes - Ramaria molleriana was described from São Tomé in 1890, based on material collected by Moller in 1887, and subsequently reported from the DR Congo (Corner 1966), Cameroon (Roberts 1999) and elsewhere in tropical Africa and Asia (Corner (1950). It was reported by Bresadola and Roumeguere (1890) and Corner (1950) to have smooth spores, although the type specimen was indicated to have angular-roughened or rugulose basidiospores (Petersen 1975, Roberts 1999). No São Tomé material was examined for this study.

Ramaria polypus Corner, Ann. Bot. Mem. 1: 700. 1950

Facesoffungi number: FoF 01068

Figs. 4, 5e

Basidiomes coralloid, 20-30 × 12-30 mm, highly branched. Stipe connivent or branched from the base, $2-10 \times 1.5-3 \mathrm{~mm}$, round or slightly compressed; branches dichotomous, $0.5-1.5$ mm diam, axils rounded; tips 1-3-fid, short, acute; surface smooth, glabrous; stipe and branches pale yellow to cream or pale orange (4-5A3-4), tips paler; stipe base with white tomentum, arising from thick, white rhizomorphs. Odor fruity, sweet.

Basidiospores 7-8.3 × 4.2-5.2 $\mu \mathrm{m}$, ellipsoid, verrucose, yellowish brown. Basidia 4-spored, clamped. Cystidia absent. Hyphae hyaline, non-inflated, clamped.

Habitat and known distribution - Solitary to scattered on rotten wood in secondary forests. Africa (São Tomé), Malaysia, Papua New Guinea, Singapore.

Material examined - Africa, São Tomé island, Parque Nacional Obo, trail to Lagoa Amelia, between N0 ${ }^{\circ} 17.112^{\prime}, \mathrm{E}^{\circ} 35.967^{\prime}$ and N0 ${ }^{\circ} 16.922^{\prime}, \mathrm{E}^{\circ} 36.062^{\prime}, 14$ April 2008, coll. by D.E. Desjardin, DED8247 (SFSU).

Notes - Described originally from Malaysia, this is the first report of Ramaria polypus from Africa. Lachnocladium ochraceum Bres., currently accepted as Ramaria ochracea (Bres.) Corner, was described from the DR Congo and may represent this species, but its basidiospores are reported as 5-5.5 × 3-3.5 $\mu \mathrm{m}$. Corner (1966) reported $R$. flaccida (Fr.) Ricken from the DR Congo, (accepting Ramaria ochracea as a synonym), but the latter forms more deeply pigmented, ochraceous to brownish ochre basidiomes. 


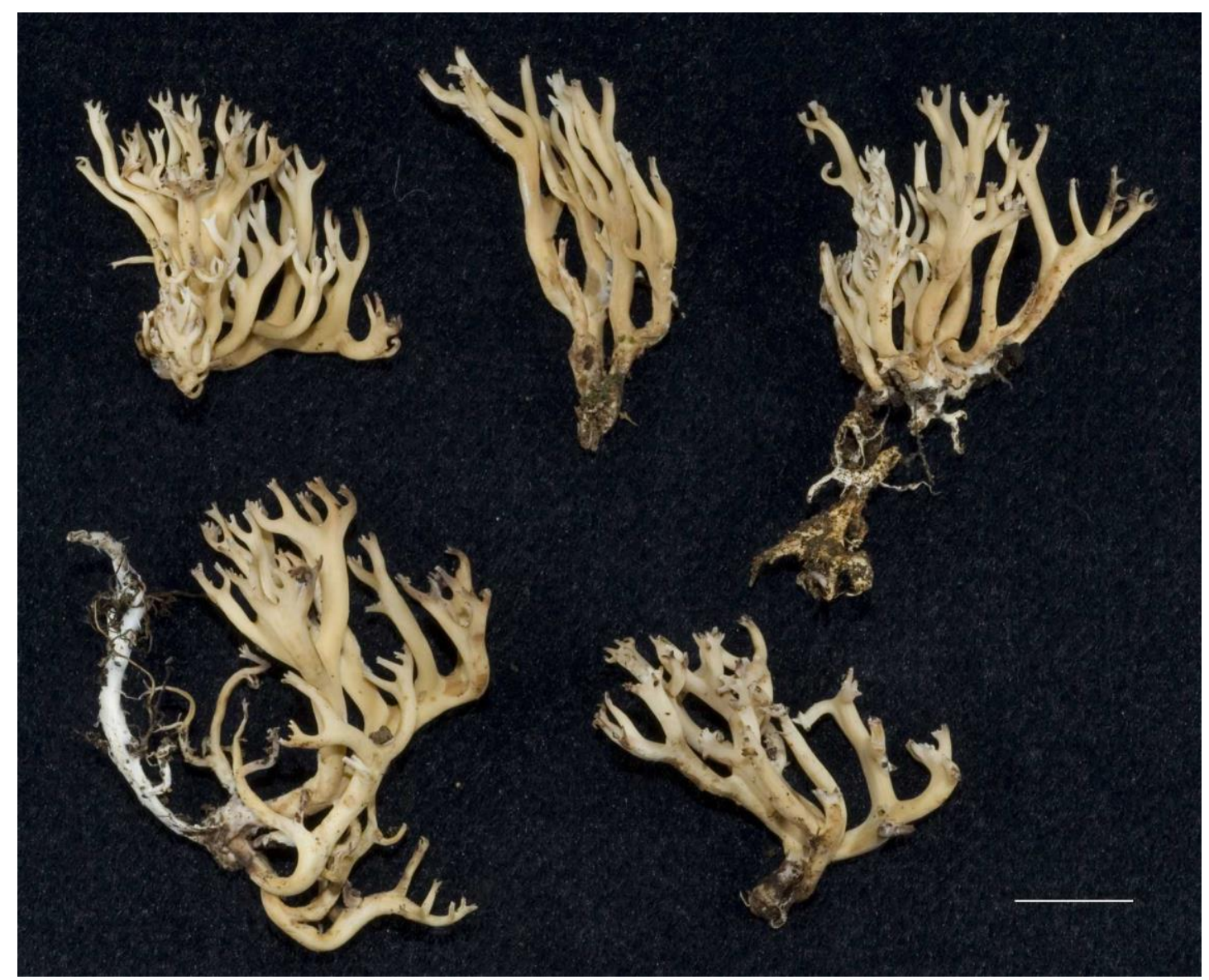

Fig. 4 - Basidiomes of Ramaria polypus (DED8247). Scale bar $=10 \mathrm{~mm}$.

Scytinopogon havencampii Desjardin \& B.A. Perry, Mycosphere 6(4): 434-441. 2015. Facesoffungi number: FoF 01069

Notes - This unusual species was recently described from material collected on Príncipe island. See the protologue for details.

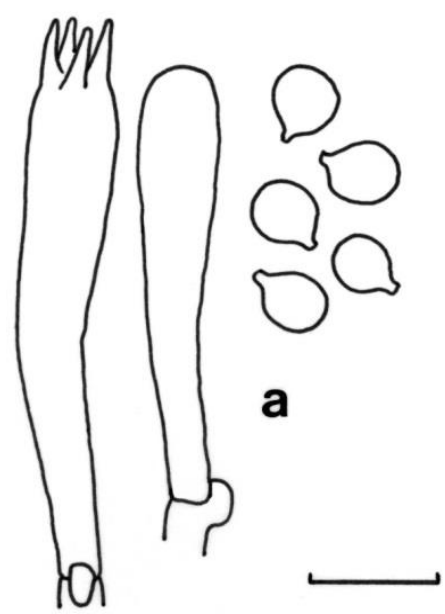

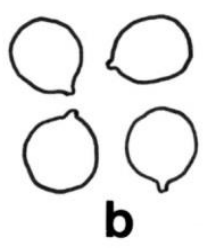
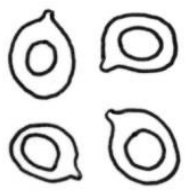

d

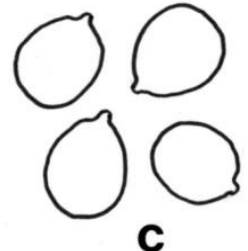

C
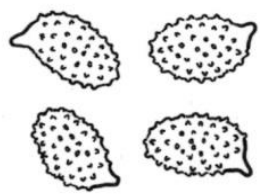

e

Figs 5 a-e - Micromorphological features of clavarioid fungi from São Tomé and Príncipe. a. Basidia and basidiospores of Aphelaria subglobispora (DED8317). b. Basidiospores of Clavaria phoenicea (BAP643). c. Basidiospores of Clavulina vanderystii (BAP647). d. Basidiospores of Clavulinopsis amoena (BAP642). e. Basidiospores of Ramaria polypus (DED8247). Scale bar $=10$ $\mu \mathrm{m}$ 


\section{Gasteromycetes}

Fourteen species of gasteromycetes are reported herein from the islands. Three of these were described originally from São Tomé island (Bresadola \& Roumeguère 1890), two species were reported earlier from São Tomé (Degreef et al. 2013), and the remaining nine species are first reports for the Republic.

Blumenavia angolensis (Welw. \& Curr.) Dring, Kew Bull. 35(1): 53. 1980.

Fig. 6 Facesoffungi number: FoF 01070

Basionym: Laternea angolensis Welw. \& Curr., Trans. Linn. Soc. London 26: 286. 1870.

Notes - The species was recently reported with full description and photograph from São Tomé (Degreef et al. 2013). See there for details.

The specimen illustrated here was collected by Miko Nadel on bamboo litter, São Tomé, along the road between São Luis and Chamico, N0¹8'23.6", E6 36'24.5", 8 May 2013. The specimen was not retained.

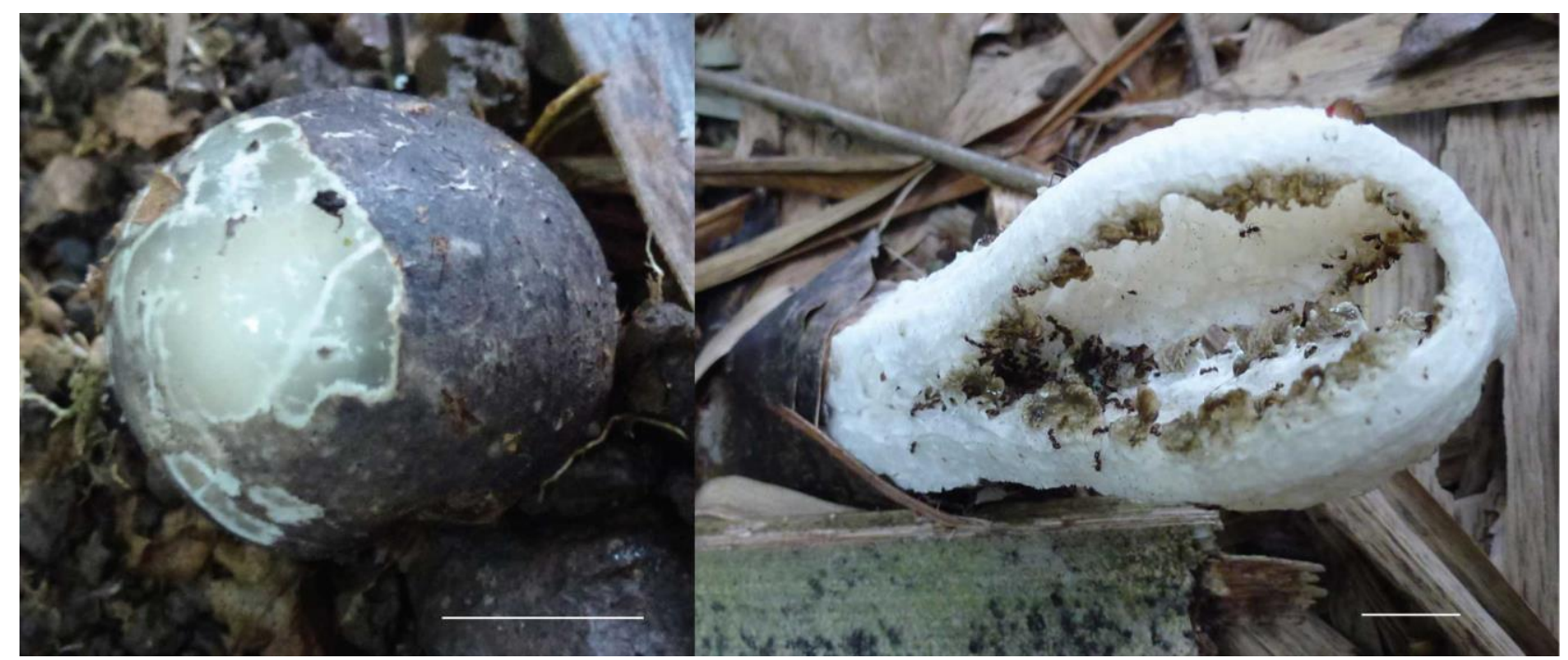

Fig 6 - An egg (left) and mature basidiome (right) of Blumenavia angolensis. Scale bars = $10 \mathrm{~mm}$.

Clathrus parvulus Bres. \& Roum., Revue Mycol., Toulouse 12: 37. 1890.

Notes - Clathrus parvulus was described from São Tomé in 1890, based on a single specimen and the species has apparently not been encountered on the island since. Dring (1964) repeated the protologue and reported a second specimen from Nigeria. No material was examined for this study.

Cyathus limbatus Tul. \& C. Tul., Annls Sci. Nat. Bot., sér. 3, 1: 78. 1844.

Facesoffungi number: FoF 01071

Notes on macromorphology not taken; macro-features indistinguishable from C. poeppigii.

Basidiospores 17-23 × 9.5-13 $\mu \mathrm{m}$, ellipsoid, smooth, hyaline, thick-walled.

Habitat and known distribution - Gregarious on rotten wood in primary and secondary forests. Common and abundant throughout tropical regions of the world.

Material examined - Africa, São Tomé island, Parque Nacional Obo, trail to Lagoa Amelia, between $\mathrm{N} 0^{\circ} 17.112^{\prime}, \mathrm{E}^{\circ} 35.967^{\prime}$ and $\mathrm{N} 0^{\circ} 16.922^{\prime}, \mathrm{E}^{\circ}{ }^{\circ} 36.062^{\prime}, 14$ April 2008, coll. by D.E. Desjardin, DED8239 (SFSU).

Notes - Cyathus limbatus is rather common in Africa, reported from the DR Congo (Dissing \& Lange 1962), Cameroon, Ghana, Nigeria, Sierra Leone (Dring 1964), Kenya, Tanzania, Uganda, Zambia and Mauritius (Dring \& Rayner 1967). 
Facesoffungi number: FoF 01072

Cup obconical, base not constricted, sides relatively straight or with a slightly flared lip; at maturity $8-10 \mathrm{~mm}$ tall $\times 7-10 \mathrm{~mm}$ diam; exterior surface tomentose with small tufts, at first brownish orange (5C4) to brownish yellow (5C5) overall, in age brown (5E4-6) to dark brown (5F4-5) with a dark brown basal mycelial pad; interior plicate, dark grayish brown (5-6F3-4) to dark brown (6-7F4-6), slightly paler when young. Epiphragm initially covered with short grayish orange hairs, glabrescent, pure white just before dehiscence. Peridioles 6-8 per cup, $1.25-1.5 \mathrm{~mm}$ diam, circular, flattened, dark grayish brown (6-7F3-4) to dark brown (6-7F4-5), attached by a dark brown funiculus.

Basidiospores 35-39 × 24-26 $\mu \mathrm{m}$, broadly ellipsoid, smooth, hyaline, thick-walled.

Habitat and known distribution - Gregarious on rotten wood in primary and secondary forests. Common and abundant throughout tropical regions of the world.

Material examined - Africa, Príncipe island, along road to Roca Pico Papagaio, N1 ${ }^{\circ} 38.600^{\prime}$, E7²3.827', 21 April 2008, coll. by D.E. Desjardin, DED8290 (SFSU).

Notes - Cyathus poeppigii, like C. limbatus, is common in Africa and the two species are easily confused in the field, distinguished primarily by micromorphology - the basidiospores of $C$. poeppigii are twice as large as those of $C$. limbatus. In Africa, C. poeppigii has been reported from the DR Congo (Dissing \& Lange 1962), Cameroon, Equatorial Guinea (Annobon), Ghana, Sierra Leone (Dring 1964), Kenya, Uganda (Dring \& Rayner 1967) and South Africa (Bottomley 1948).

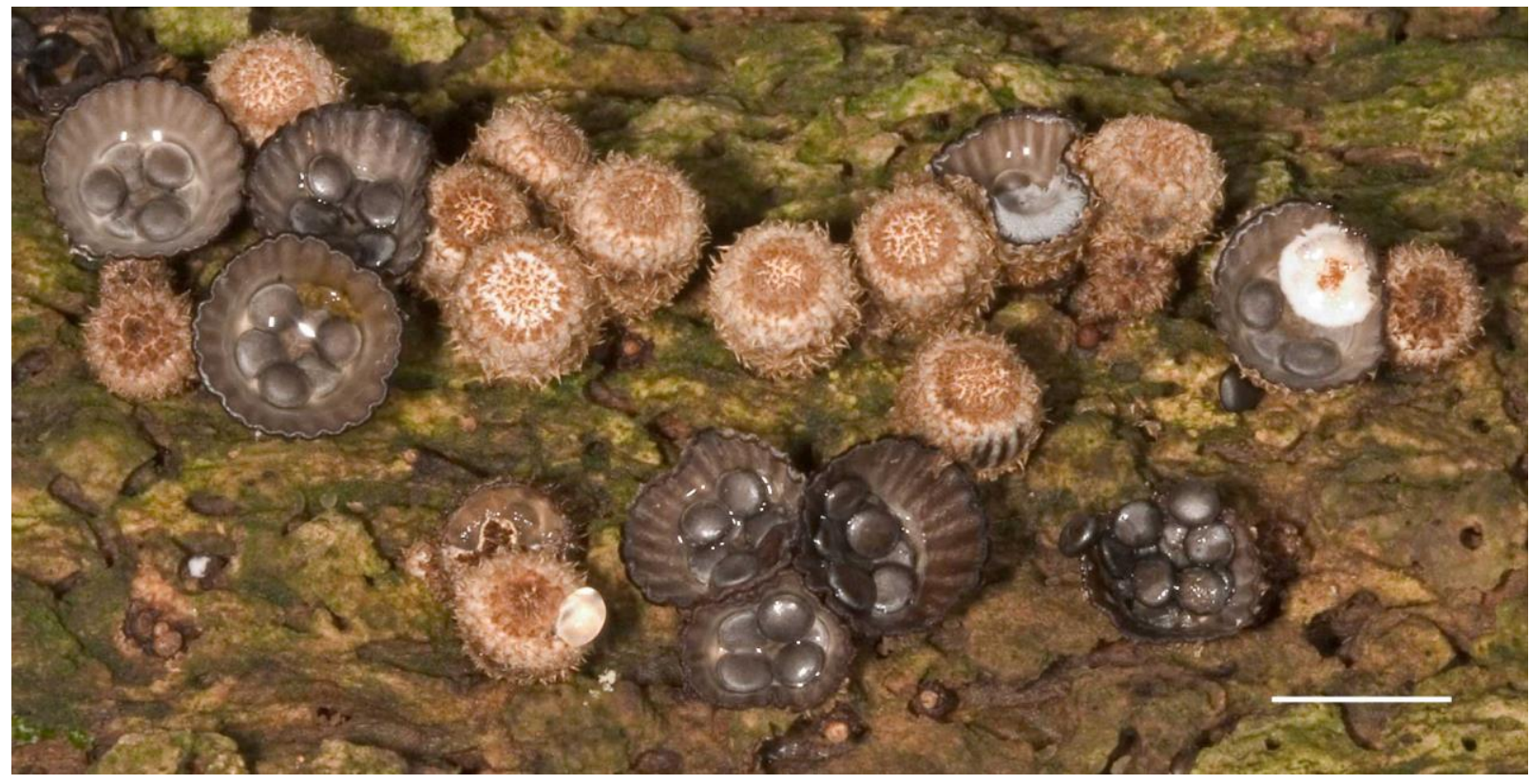

Fig. 7 - Basidiomes of Cyathus poeppigii (DED8290). Scale bar $=10 \mathrm{~mm}$.

Geastrum fimbriatum Fr., Syst. Mycol. (Lundae) 3(1): 16. 1829.

Fig. 8 Facesoffungi number: FoF 01073

Expanded basidiomes $25-35 \mathrm{~mm}$ diam, with 6-7 recurved rays, not hygroscopic; external surface of exoperidium (mycelial layer) adhering debris and soil, attached to coarse white rhizomorphs, surface tomentose, covered with tufted, cream (4A3) mycelium; pseudoparenchymatous layer glabrous, pale brownish grey (6C3), darkening in age to brown (6E4); endoperidium saccate, not stipitate, $14-17 \mathrm{~mm}$ diam, ovoid, surface finely felted, dark grayish brown (6F3); peristome finely fibrillose, not delimited, concolorous.

Basidiospores 3.5-4.0 $\mu \mathrm{m}$ including ornamentation, globose, finely verruculose, dark grayish brown. 
Habitat and known distribution - Scattered over soil in a coastal cacao-banana grove. Widely distributed.

Material examined - Africa, São Tomé island, along road to Bombain, $400 \mathrm{~m}$ elev., N0 16.615', E6 ${ }^{\circ} 38.942 ', 26$ April 2008, coll. by D.E. Desjardin, DED8335 (SFSU).

Notes - We suspect that the São Tomé taxon was reported as G. rufescens Pers. emend. Waveren by Dissing and Lange (1962) based on material from the DR Congo. The latter is accepted as a synonym of G. fimbriatum by Sunhede (1989) (non G. rufescens Pers. sensu stricto). The São Tomé material is readily distinguished by a well-developed mycelial layer that adheres debris, a saccate, non-stipitate endoperidium with dark grayish brown, felted surface, a nondelimited, fibrillose peristome, and small (3.5-4.0 $\mu \mathrm{m}$ diam), verruculose basidiospores.

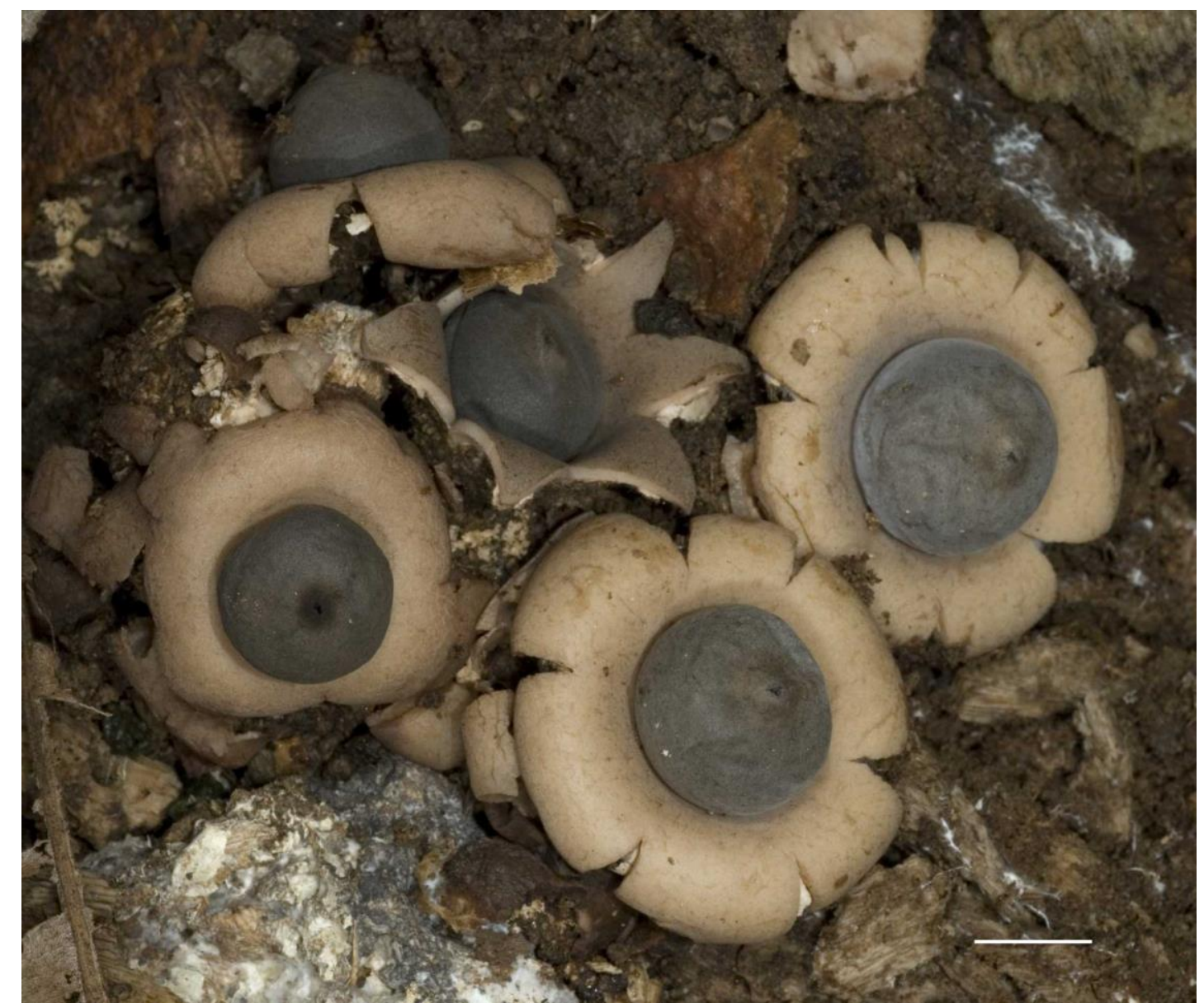

Fig. 8 - Basidiomes of Geastrum fimbriatum (DED8335). Scale bar $=10 \mathrm{~mm}$.

Geastrum schweinitzii (Berk. \& M.A. Curtis) Zeller, Mycologia 40(6): 649. 1948. Facesoffungi number: FoF 01074

Fig. 9

Basionym: Coilomyces schweinitzii Berk. \& M.A. Curtis, J. Acad. Nat. Sci. Philad., N.S. 2(6): 279. 1854 (1853).

= Geastrum mirabile Mont., Ann. Sci. Nat. Bot. 3: 139. 1855.

Unexpanded basidiomes 7-10 $\mathrm{mm}$ tall $\times 4-10 \mathrm{~mm}$ diam, ovoid, seldom with a rounded papilla, arising from a well-developed, membranous, white to cream (4A3) subiculum that covers the substrate; expanded basidiomes 8-13 (-17) mm diam, with 5-7 recurved rays, not hygroscopic; external surface of exoperidium (mycelial layer) not adhering debris, glabrous or with scattered appressed-felted patches, dingy buff to pale brownish orange (5C4) or pale brownish gray (6C3); pseudoparenchymatous layer glabrous, dingy buff to cream (4A3); endoperidium saccate, not stipitate, 4-8 $\mathrm{mm}$ diam, globose to subglobose, glabrous, grayish brown (6D3); peristome fibrillose, slightly delimited by a paler circular zone, concolorous or dark brown. 
Basidiospores 3.8-4.5 $\mu \mathrm{m}$ including ornamentation, globose, verrucose, dark brown. Capillitia 2.2-3.8 $\mu \mathrm{m}$ diam, unbranched, cylindrical or irregular in outline, thick-walled, subhyaline to brown.

Habitat and known distribution - Densely gregarious on a membranous subiculum that covers rotten wood. Widely distributed in tropical habitats.

Material examined - Africa, Príncipe island, Bom Bom resort, N1 ${ }^{\circ} 41.559^{\prime}, \mathrm{E}^{\circ} 24.171^{\prime}, 20$ April 2008, coll. by D.E. Desjardin, DED8273 (SFSU); São Tomé island, Macambrara radio antenna area, $1300 \mathrm{~m}$ elev., N0 ${ }^{\circ} 16.557^{\prime}, \mathrm{E}^{\circ} 36.326^{\prime}, 11$ April 2008, coll. by D.E Desjardin, DED8212 (SFSU).

Notes - Geastrum schweinitzii, originally described from Surinam, has been reported from Mauritius and Uganda (Dring \& Rayner 1967), and as G. mirabile (type locality Guyana) from the DR Congo (Dissing \& Lange 1962), Ghana, Nigeria (Dring 1964) and South Africa (Bottomley 1948). We suspect that G. subiculosum Cooke \& Massee (type locality Australia), reported from the DR Congo (Dissing \& Lange 1962) may represent the same species varying only slightly in subiculum color, structure and basidiospore size.

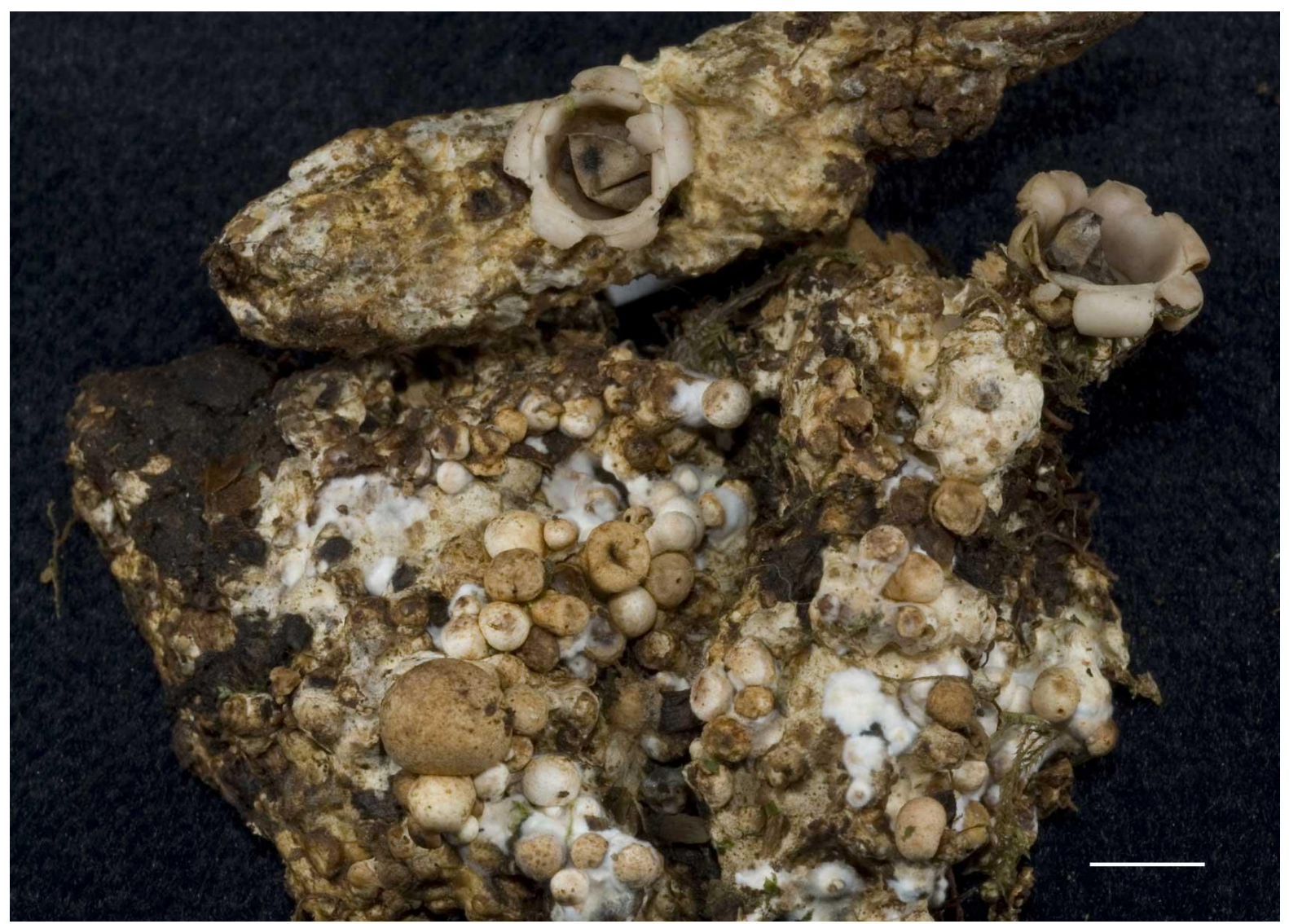

Fig. 9 - Basidiomes of Geastrum schweinitzii (DED8212). Scale bar $=10 \mathrm{~mm}$.

Geastrum velutinum Morgan, J. Cincinnati Soc. Nat. Hist. 18: 38. 1895.

Fig. 10

Facesoffungi number: FoF 01075

Expanded basidiomes 20-25 $\mathrm{mm}$ diam, with 7-8 recurved rays, not hygroscopic; external surface of exoperidium (mycelial layer) not adhering debris, deeply felted, cream (4A3) to grayish orange (5B4-5); pseudoparenchymatous layer glabrous, pinkish buff (5A3); endoperidium saccate, not stipitate, 7-10 mm diam, ovoid, minutely felted to suede-like, brownish gray (6C3) to grayish brown (6D-E3); peristome fibrillose, delimited by a paler, cream (4A3) circular zone.

Basidiospores 3.2-4.0 $\mu \mathrm{m}$ including ornamentation, globose, coarsely verrucose, brown. Capillitia 2.5-4.2 $\mu \mathrm{m}$ diam, unbranched, cylindrical, smooth or roughened, thick-walled, subhyaline to yellowish brown. 
Habitat and known distribution - Solitary in soil under baobob and mesquite in xerophytic coastal habitat. Widely distributed.

Material examined - Africa, São Tomé island, along main road (EN-1) on north side of island at $16.5 \mathrm{~km}$ marker, N0 24.374', E6 37.092', 17 April 2008, coll. by D.E. Desjardin, DED8249 (SFSU).

Notes - Geastrum velutinum has been reported from the DR Congo (Dissing \& Lange (1962), Ghana, Nigeria (Dring 1964), Kenya, Uganda (Dring \& Rayner 1967) and South Africa (Bottomley 1948). On São Tomé, the species has been found only once in a xerophytic habitat with mesquite and baobob trees.

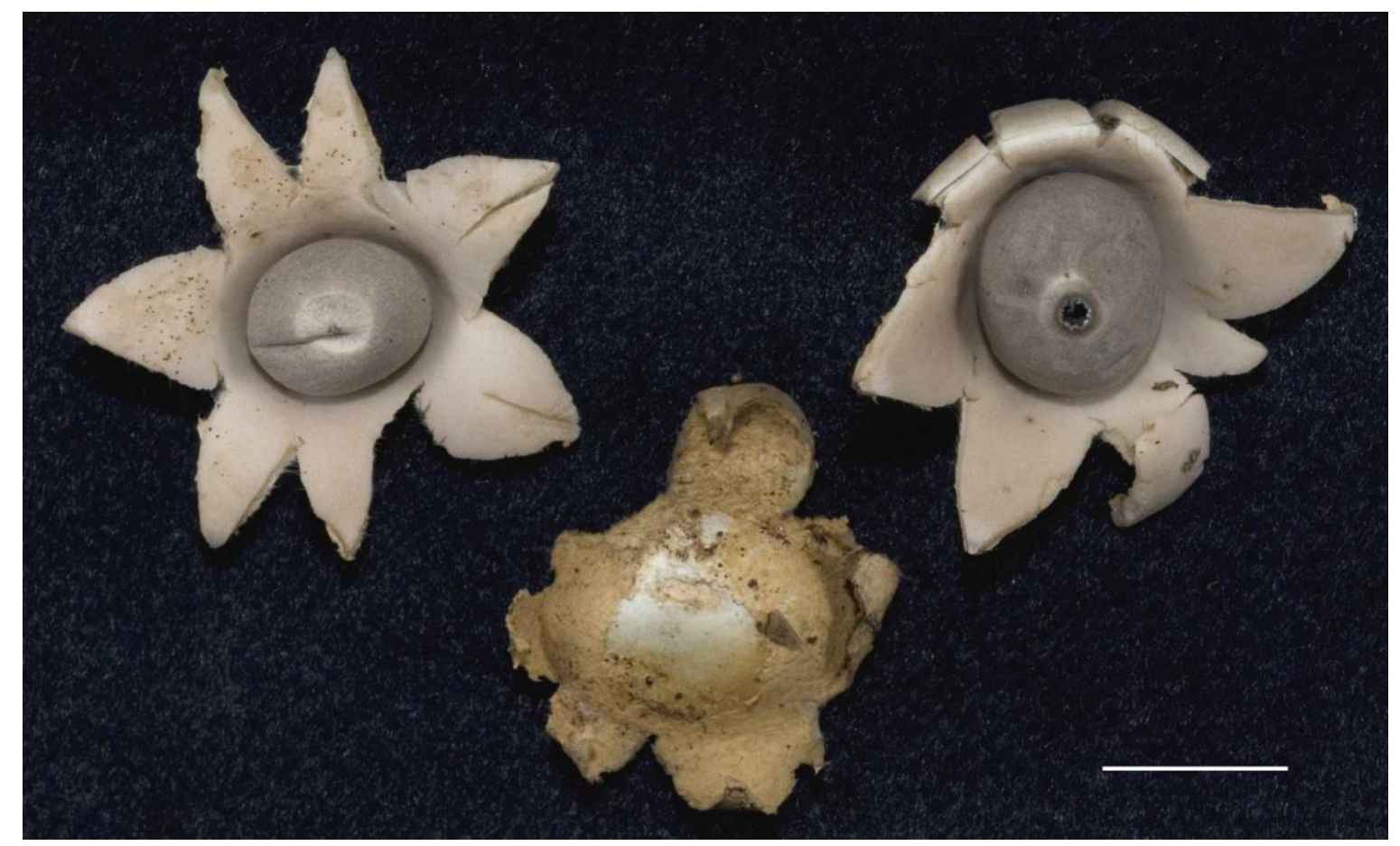

Fig. 10 - Basidiomes of Geastrum velutinum (DED8249). Scale bar $=10 \mathrm{~mm}$.

Lycoperdon molle Pers., Syn. Meth. Fung. (Göttingen) 1: 150. 1801.

Fig. 11

Facesoffungi number: FoF 01076

Basidiome ovoid in face view, $32 \times 26 \mathrm{~mm}$ diam, broadly pyriform in profile, $20 \mathrm{~mm}$ diam with a subgleba $10 \mathrm{~mm}$ tall; ostile area with dense, dark grayish brown (7F4) spines $<0.5 \mathrm{~mm}$ tall, elsewhere granulose to spinose, ornamentation brown (7E4) to grayish brown (7E3) over pale grayish white ground color. Peridium $<1 \mathrm{~mm}$ thick, white. Gleba white when immature. Subgleba with tiny chambers, white; diaphragm absent.

Basidiospores and capillitia not observed; single basidiome immature.

Habitat and known distribution - Solitary in soil in secondary forest. Widely distributed in temperate regions.

Material examined - Africa, Príncipe island, on east side of island at the base of Dois Irmãos, N1 ${ }^{\circ} 34.889^{\prime}, \mathrm{E7}^{\circ} 25.548^{\prime}, 23$ April 2008, coll. by D.E. Desjardin, DED8315 (SFSU).

Notes - Unfortunately, the single basidiome encountered was immature and its identification is based on overall macromorphological similarity with this well known species. The exoperidium features of the Príncipe specimen do not match those of any species reported from Africa by Bottomley (1948), Dissing and Lange (1962), Dring (1964) or Dring and Rayner (1967). Mature material is needed to confirm the identification. 


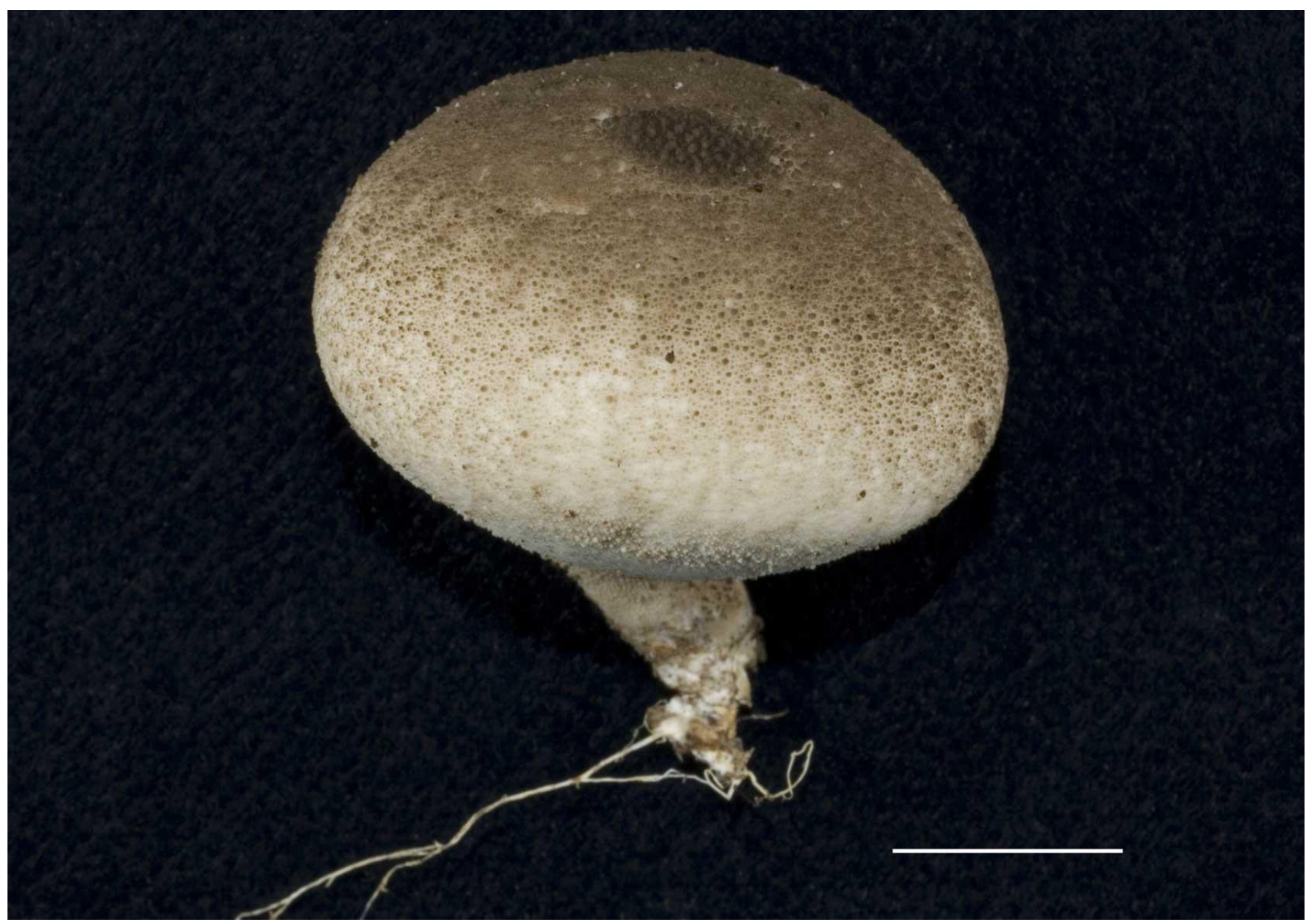

Fig. 11 - Basidiome of Lycoperdon molle (DED8315). Scale bar $=10 \mathrm{~mm}$.

Mutinus bambusinus (Zoll.) E. Fisch., Ann. Jard. Bot. Buitenzorg 6: 30. 1886.

Facesoffungi number: FoF 01077

Basionym: Phallus bambusinus Zoll., Natuur-Geneesk. Arch. Ned.-Indië 1: 11. 1854.

Eggs 18-23 mm tall $\times 16-18 \mathrm{~mm}$ diam, globose to ovoid, rooting, surface furfuraceous, grayish brown (7E3) above, white below, dehiscing by an apical slit. Receptacle 110-120 mm tall; fertile portion conical, 22-26 mm tall $\times 3-4 \mathrm{~mm}$ (apex) $\times 10-11 \mathrm{~mm}$ (base), bright red (9B7-8), pustulate-warted, coated with a dark olive brown, mucilaginous gleba, covering upper $25 \%$ of receptacle but with a sterile tip 8-10 mm long, conical, white to cream (4A3); infertile portion (pseudostipe) cylindrical, $80 \times 10-11 \mathrm{~mm}$, cylindrical, hollow, rubbery, chambered-pitted, chambers opening to the exterior, dry, apex orangish white (6A2), base white. Odor strong.

Basidiospores 3.5-5.0 × 1.5-2.0 $\mu \mathrm{m}$, ellipsoid, smooth, olivaceous, thin-walled.

Habitat and known distribution - Solitary in soil in secondary forests. Widely distributed in tropical regions.

Material examined - Africa, Príncipe island, Roca Pico Papagaio, N1³7.182', E7 23.474', 21 April 2008, coll. by B.A. Perry and D.E. Desjardin, DED8282 (SFSU).

Notes - Mutinus bambusinus is a widespread and variable species. The Príncipe material has a grayish brown, furfuraceous egg, a chambered pseudostipe with chambers that open to the exterior, and a fertile portion topped with a conical sterile tip, similar to populations from south Asia (Petch 1926). The species has been reported in Africa from Ghana (Dring 1964; although the specimen illustrated more closely represents M. argentinus Speg.), DR Congo (Demoulin \& Dring 1975), and South Africa (Bottomley 1948).

Mutinus zenkeri (Henn.) E. Fisch., Neu Denkschr. Schwein. Naturf. Ges. 36: 47. 1900. $\quad$ Fig. 13 Facesoffungi number: FoF 01078

Basionym: Floccomutinus zenkeri Henn., in Engler, Bot. Jb. 22: 109. 1895. 


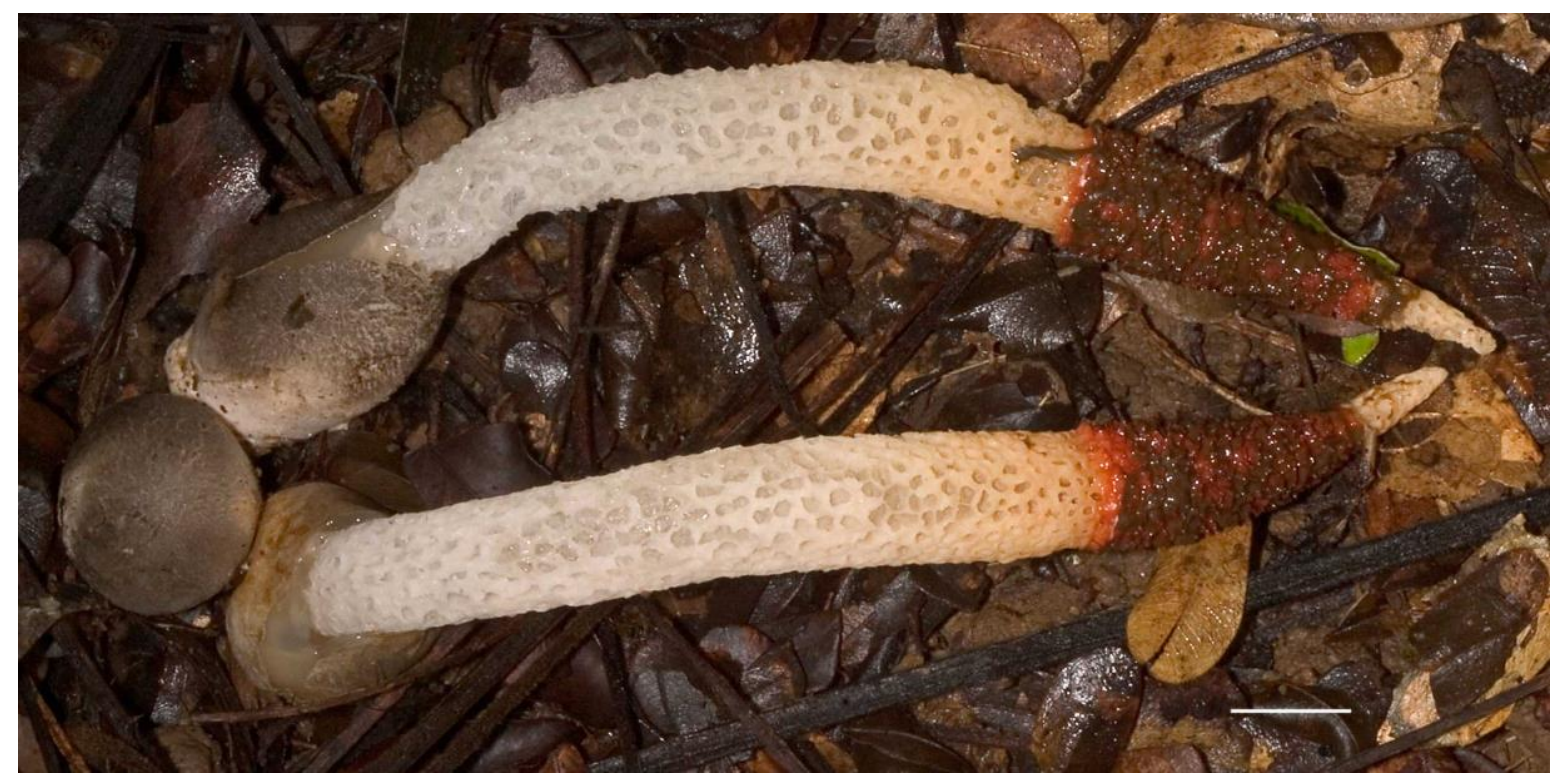

Fig. 12 - Basidiomes of Mutinus bambusinus (DED8282). Scale bar $=10 \mathrm{~mm}$.

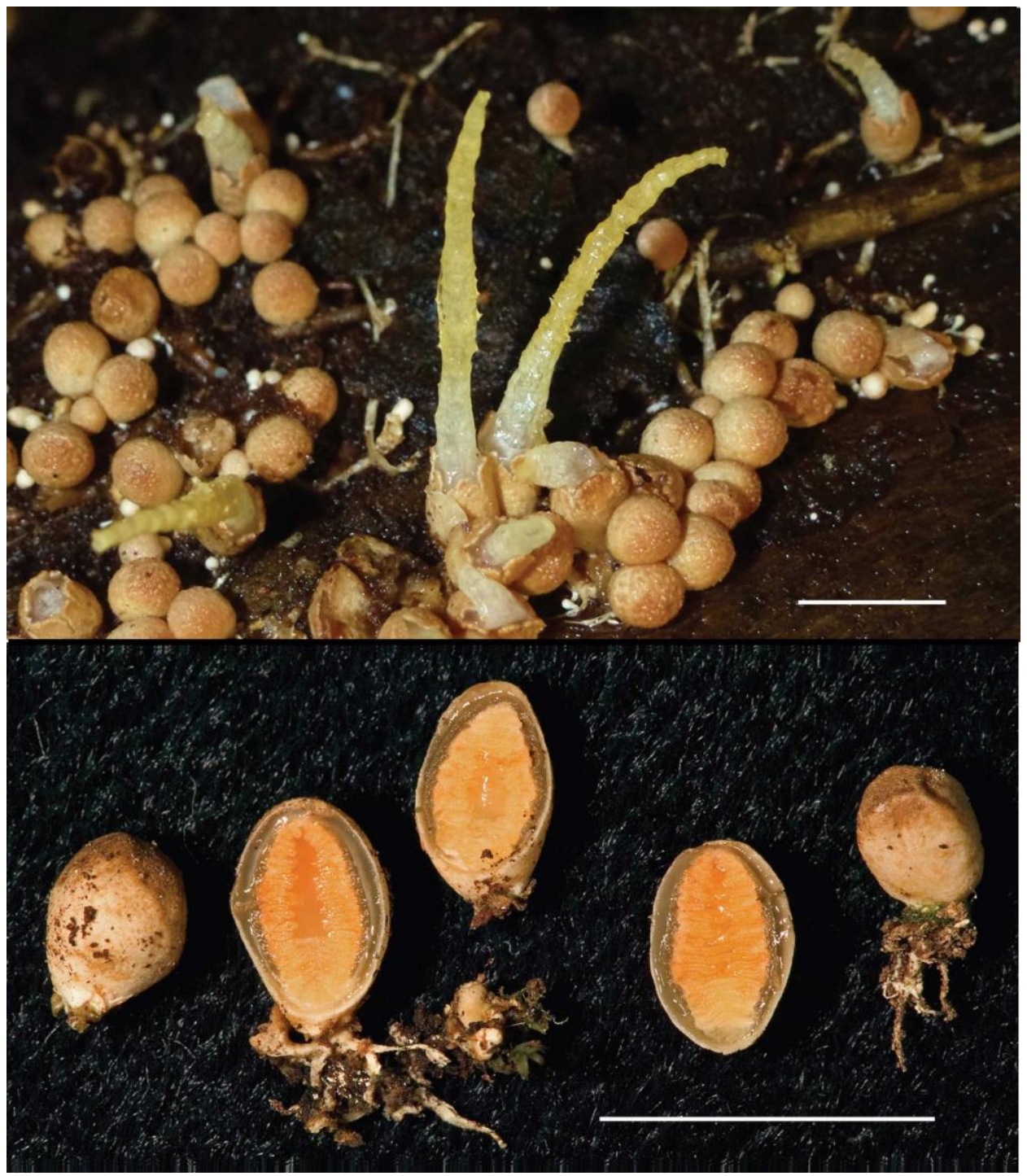

Fig. 13 - Basidiomes of Mutinus zenkeri from Príncipe (top, MN0500) and unopened eggs from São Tomé (bottom, DED8214). Scale bars $=10 \mathrm{~mm}$. 
Material examined - Africa, Príncipe island, Pico Mesa, N1³4'56.2", E7²1'04.4", 19 April 2013, coll. by Miko Nadel, MN0500 (SFSU); São Tomé island, Macambrara radio antenna area, 1300 m elev., N0¹6.557', E6³6.326', 11 April 2008, coll. by D.E Desjardin, DED8214 (SFSU).

Notes - The species was recently reported with full description and photograph from São Tomé (Degreef et al. 2013). See there for details. The specimen illustrated here was collected on decomposing wood on Príncipe. The species was also encountered several times on São Tomé in Obo National Park but material was not retained.

Phallus drewesii Desjardin \& B.A. Perry, Mycologia 101(4): 545. 2009

Fig. 14

Facesoffungi number: FoF 01079

Notes - The species was described recently from material collected on the sides of fallen logs, on the trail to Lagoa Amelia, Obo National Park, São Tomé (Desjardin \& Perry 2009). See there for details. The material reported from Tanzania as Phallus tenuis (Härkönen et al 2003) may represent $P$. drewesii. A recent report of $P$. drewesii from Vietnam (Trierveiler-Pereira \& Thao 2013) is erroneous, the material most likely representing $P$. flavocostatus Kreisel.

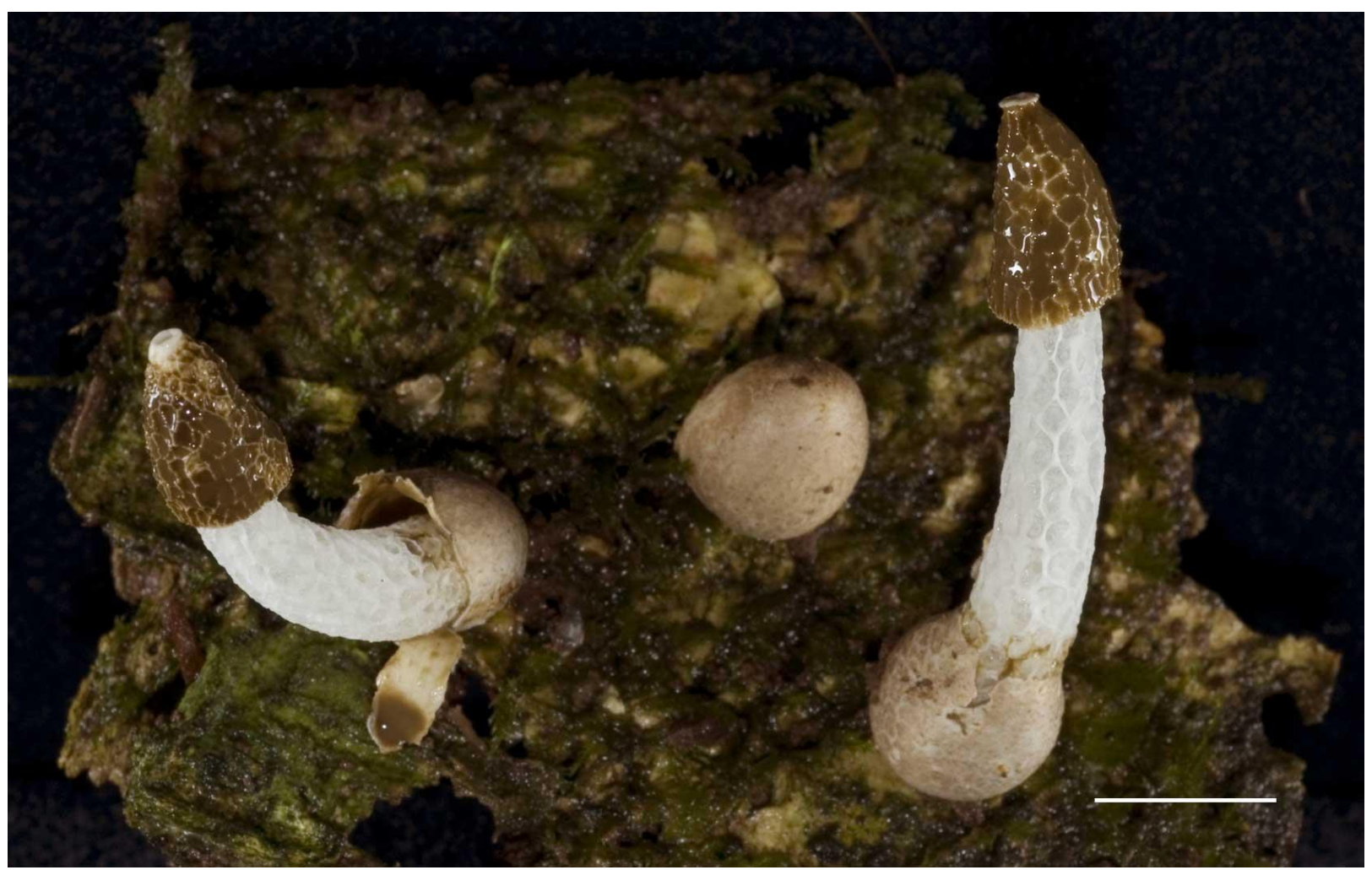

Fig. 14 - Basidiomes of Phallus drewesii (DED8227). Scale bar $=10 \mathrm{~mm}$

Phallus indusiatus Vent., Mém. Inst. Nat. Sci. Arts 1: 520. 1798.

Fig. 15

Facesoffungi number: FoF 01080

= Dictyophora indusiata (Vent.) Desv., J. Bot., Paris 2: 92.1809.

Eggs $40-45 \mathrm{~mm}$ tall $\times 40 \mathrm{~mm}$ diam, globose to obovoid, rooting, arising from copious, coarse white rhizomorphs, surface glabrous, dark gray, areolate just before dehiscing by an apical slit. Receptacle 140-180 mm tall. Pileus 35-40 × 38-40 mm, flattened-conical to campanulate, perforate at apex, perforation $8-10 \mathrm{~mm}$ diam, white-rimmed; surface coarsely wrinkled, creamolive (4A3 with hint of olive). Gleba deep olive-grayish brown, mucilaginous. Pseudostipe 120$140 \times 28-33 \mathrm{~mm}$, cylindrical, hollow, spongy-chambered, $5 \mathrm{~mm}$ thick, dry, brittle, white. Indusium well-developed, hanging $45-50 \mathrm{~mm}$ or more, perforations $2-8 \mathrm{~mm}$ diam, angular, white.

Basidiospores 2.5-3.5 × 1.0-1.5 $\mu \mathrm{m}$, ellipsoid, smooth, olivaceous, thin-walled. 
Habitat and known distribution - Scattered on the end of a well-decayed log in secondary forest. Widely distributed in tropical regions.

Material examined - Africa, Príncipe island, Bom Bom resort, N1 ${ }^{\circ} 41.559^{\prime}, \mathrm{E}^{\circ} 24.171^{\prime}, 23$ April 2008, coll. by B.A. Perry and D.E. Desjardin, DED8322 (SFSU).

Notes - Phallus indusiatus is one of the more commonly encountered phalloids in tropical regions. Selected reports from Africa include DR Congo (Dissing \& Lange 1962), Cameroon, Equatorial Guinea (Fernando Po), Ghana, Nigeria, Sierra Leone (Dring 1964), Tanzania, Uganda (Dring \& Rayner 1967), and South Africa (Bottomley 1948).

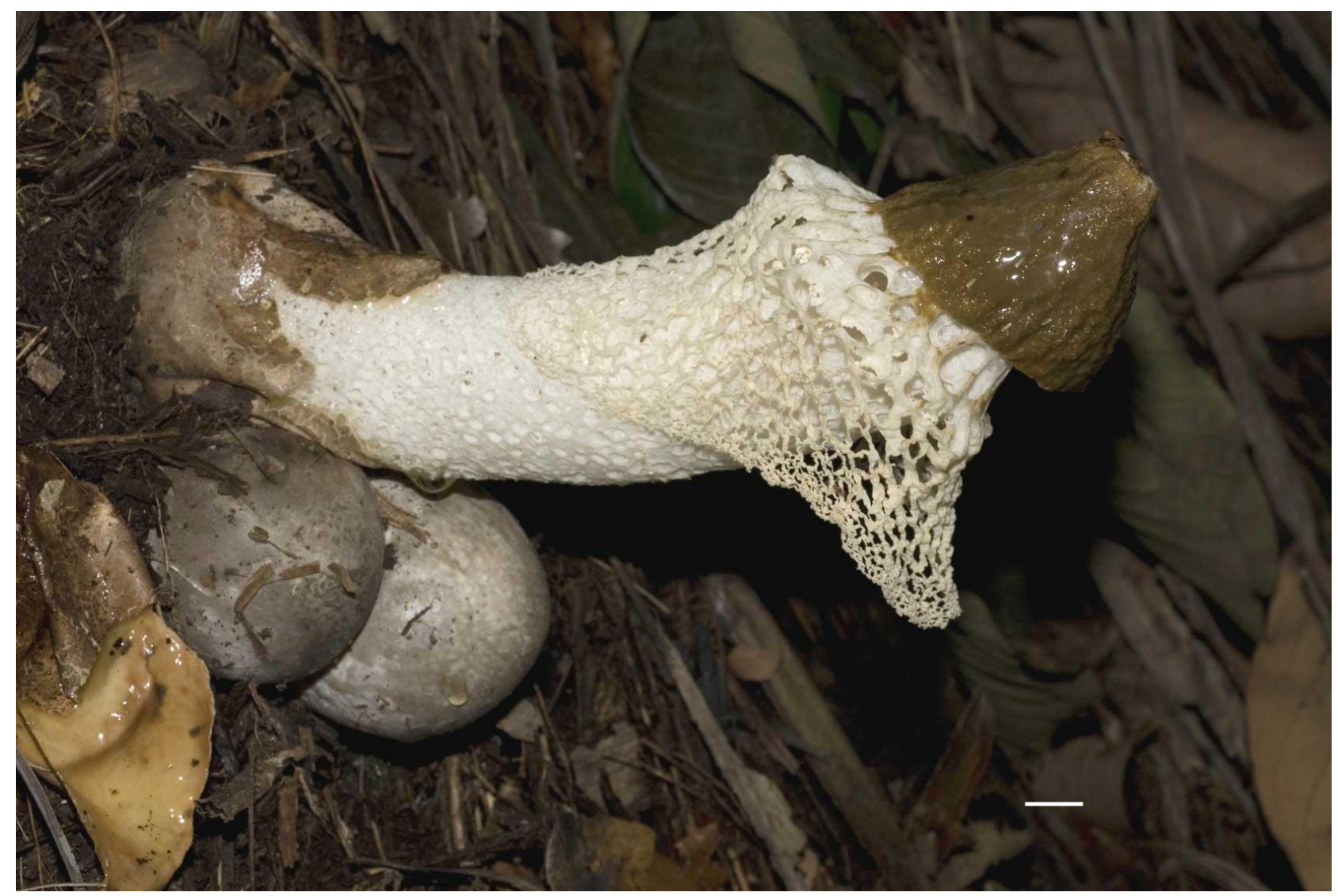

Fig. 15 - Mature basidiome and eggs of Phallus indusiatus (DED8322). Scale bar $=10 \mathrm{~mm}$.

Scleroderma dictyosporum Pat., Bull. Soc. Mycol. Fr. 12(3): 135. 1896.

Fig. 16

Facesoffungi number: FoF 01081

Basidiomes 7-12 mm diam, ovoid, surface covered with brown (6-7E6-8) granular, irregular warts $<0.2 \mathrm{~mm}$ diam, on a cream (4A3) to pale cream-brown peridium, rooted at the base by copious, white, branched rhizomorphs. Peridium $0.5 \mathrm{~mm}$ thick, soft, fragile, yellowish white (4A2), opening by several tears. Gleba dark grayish brown.

Basidiospores 7-8.5 $\mu \mathrm{m}$ diam excluding ornamentation, globose, very coarsely pustulatereticulate, ornamentation 1.3-2.5 $\mu \mathrm{m}$ tall, (10-13.5 $\mu \mathrm{m}$ diam including ornamentation), brown.

Habitat and known distribution - Solitary in soil in primary forest. Africa (Ghana, Guinea, Príncipe).

Material examined - Africa, Príncipe island, south side of island at Rio São Tomé, N1³3'40.54", E7²1'15.51", 22 April 2008, coll. by B.A. Perry, DED8310 (SFSU).

Notes - Scleroderma dictyosporum is readily identified by the coarsely pustulate-reticulate basidiospores with ornamentation up to $2.5 \mu \mathrm{m}$ tall, and small basidiomes with a thin, fragile peridium and brown spore mass. Described originally from French Guinea, it is apparently rarely collected in the paleotropics. 
Tulostoma moellerianum Bres. \& Roum., Revue Mycol., Toulouse 12: 37.1890.

Facesoffungi number: FoF 01082

Notes - Tulostoma moellerianum was described from São Tomé in 1890, based on a single specimen and the species has apparently not been encountered on the island since. No material was examined for this study.

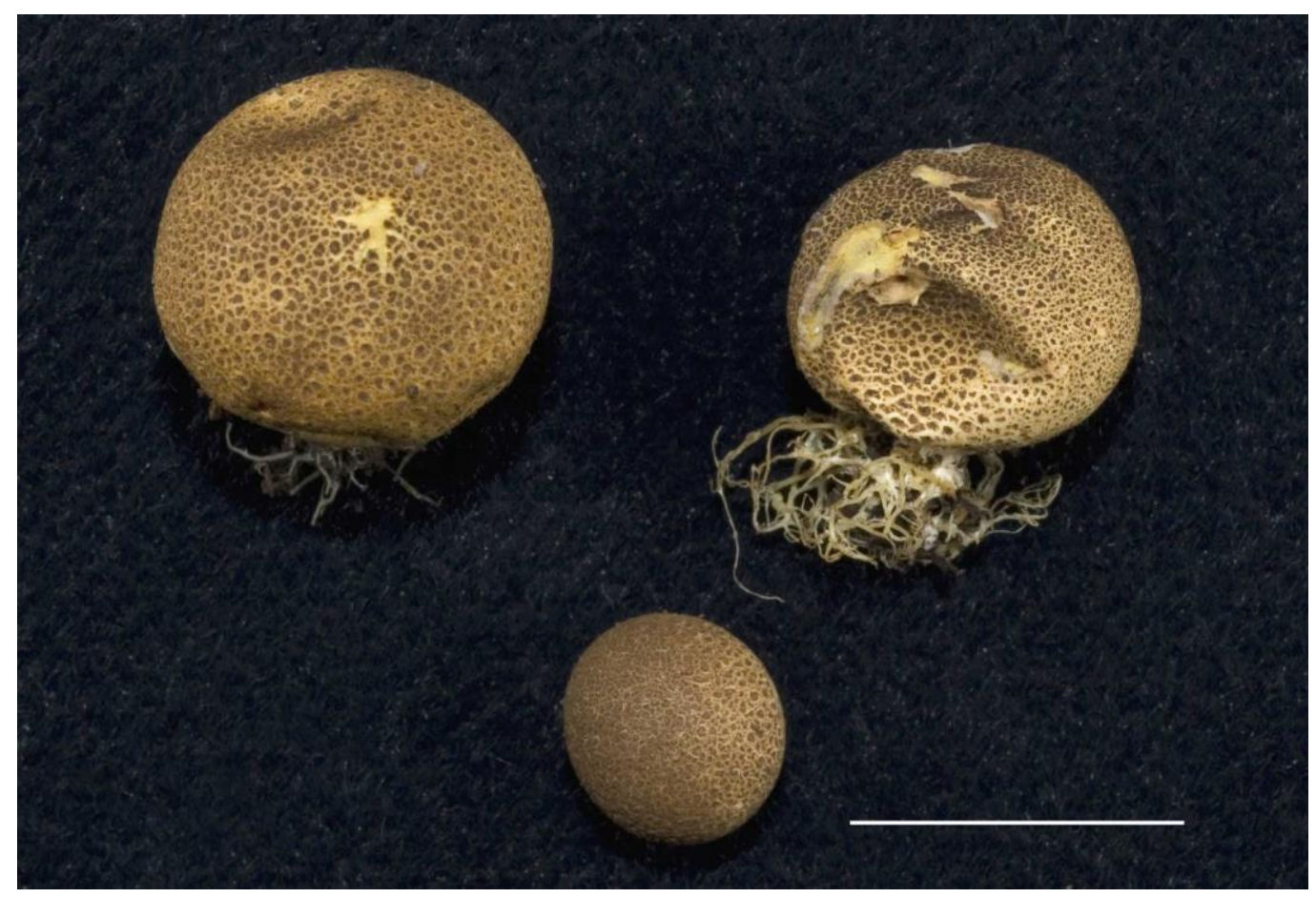

Fig. 16 - Basidiomes of Scleroderma dictyosporum (DED8310). Scale bar $=10 \mathrm{~mm}$.

\section{Acknowledgments}

Foremost we thank Dr. Robert C. Drewes who continues to initiate, coordinate and lead multiorganism biotic surveys on São Tomé and Príncipe. We thank Eng. Arlindo de Ceita Carvalho, Director General of the Ministry of Environment, Victor Bonfim, Salvador Sousa Pontes and Danilo Barbero for permission to collect and export specimens for study. We are indebted to Société de Conservation et Développement for logistics and housing support, especially the wonderful staffs of Omali Lodge and Bom Bom Island. We are grateful for the support and cooperation of Bastien Loloumb of Zuntabawe and Faustino Oliviera, former Director of the botanical garden at Bom Sucesso. We were assisted in the field by Jose Ramos Maria Vital Pires on Príncipe and by Quintino Quade Cabral, Martinho Nascimiento and Jose Clara on São Tomé. For continuing support, we are most grateful to Ned Seligman, Quintino Quade Cabral and Roberta dos Santos of STePUP. We are grateful to the College of Science and Engineering at San Francisco State University for partial funding to support travel to São Tomé and Príncipe, and to the G. Lindsay Field Research Fund of the California Academy of Sciences (CAS) for financially supporting the expedition in 2006 and the Hagey Research Venture Fund (CAS) in 2008. We thank Wes Eckerman (WE) and Miko Nadel (MN) for providing photographs of Cyathus poeppigii (WE), Blumenavia angolensis, Clavaria phoenicea and Mutinus zenkeri (MN).

\section{References}

Bottomley AM. 1948 - Gasteromycetes of South Africa. Bothalia 4(3), 473-810.

Bresadola G, Roumeguère, C. 1890 - Nouvelles contributions à la Flore mycologique des Iles Saint-Thomé et des Princes, recuilles par MM. Ad, F. Moller, F. Quintas, et F. Newton. Revue Mycologique, Toulouse 12(45), 25-40. 
Corner EJH. 1950 - A Monograph of Clavaria and Allied Genera. Annals of Botany Memoirs No. 1, Oxford University Press, London, UK. 740 p.

Corner EJH. 1966 - Clavarioid genera and Thelephora from the Congo. Bulletin du Jardin Botanique de l'Etat a Bruxelles 36(3), 257-279.

Corner EJH. 1970 - Supplement to "A Monograph of Clavaria and Allied Genera." Beihefte zur Nova Hedwigia 33, 1-299.

Degreef J, Amalfi M, Decock C, Demoulin V. 2013 - Two rare Phallales recorded from São Tomé. Cryptogamie Mycologie 34(1), 3-13.

Demoulin V, Dring DM. 1975 - Gasteromycetes of Kivu (Zaïre), Rwanda and Burundi. Bulletin du Jardin Botanique National de Belgique 45, 339-372.

Desjardin DE, Perry BA. 2009 - A new species of Phallus from São Tomé, Africa. Mycologia 101(4), 543-545.

Desjardin DE, Perry BA. 2015 - A new species of Scytinopogon from the island of Príncipe, Republic of São Tomé and Príncipe, West Africa. Mycosphere 6(4), 434-441.

Dissing H, Lange M. 1962 - Gasteromycetes of Congo. Bulletin du Jardin Botanique de l'État a Bruxelles 32(4), 325-416.

Dring DM. 1964 - Gasteromycetes of west tropical Africa. Mycological Papers (Kew) 98, 1-60.

Dring DM, Rayner RW. 1967 - Some Gasteromycetes from Eastern Africa. Journal of the East African Natural History Society 26, No. 2(114), 5-46.

Härkönen M, Tuomo N, Mwasumbi L. 2003 - Tanzanian Mushrooms. Edible, harmful and other fungi. Botanical Museum, Finnish Museum of Natural History, University of Helsinki. 200 p.

Kornerup A, Wanscher JH. 1978 - Methuen Handbook of Colour. 3rd ed. Eyre Methuen, London.

Petch T. 1926 - Mutinus bambusinus (Zoll.) Fischer. Transactions of the British Mycological Society 10, 272-282.

Petersen RH. 1975 - Ramaria subgenus Lentoramaria with emphasis on North American taxa. Bibliotheca Mycologica 43, 1-161.

Roberts P. 1999 - Clavarioid fungi from Korup National Park, Cameroon. Kew Bulletin 54, 517539.

Sunhede S. 1989 - Geastraceae (Basidiomycotina). Morphology, ecology, and systematics with special emphasis on the North European species. Synopsis Fungorum 1, 1-534.

Trierveiler-Pereira L, Thao NP. 2013 - Update on the distribution of Phallus drewesii (Phallales, Basidiomycota): new record from Asia. Mycosphere 4(5), 994-997. 